\title{
Between Sin and Salvation: The Seventeenth-Century Dutch Artisan Pieter Plockhoy and His Ethics of Work*
}

\author{
HENK L OOIJESTEIJN \\ International Institunt voor Sociale Geschiedenis, Amsterdam \\ E-mail: hlo@iisg.nl
}

Summary: There have been few attempts systematically to study the ethics of work in the early modern age on the basis of contemporary sources. Such a study should start with case studies of individual thinkers, as stepping stones to a more comprehensive study of the ethics of work. This article provides such a case study, of the seventeenth-century Dutch artisan Pieter Plockhoy (c.1620-I664). As will be shown, work was a central component of Plockhoy's philosophy of true, practical Christianity, and on the basis of his tracts a more or less coherent ethics of work can be reconstructed. Although this article concentrates on Plockhoy's philosophy of labour, his thought fits into a broader context of related contemporary thinkers, many of whom shared his concerns. Thus the article shows that for scholars wishing to study the ethics of work there is still a whole field which, though yielding a potentially rich harvest, lies fallow.

Though generations of scholars have engaged with Weber's famous thesis on the connection between Protestantism and the rise of capitalism, systematic attempts to study the ethics of work in the early modern age on the basis of contemporary sources have been limited. This is not surprising, given that in many ways the history of the idea of work is still uncharted, as Ehmer and Lis have noted. ${ }^{\mathrm{I}}$ Given this lacuna, a study of early modern work ethics should perhaps begin with studies of individual thinkers, as stepping stones to a more comprehensive study of the ethics of work.

\footnotetext{
* I would like to thank my colleagues Karin Hofmeester, Piet Lourens, Jan Lucassen, and Christine Moll-Murata, and the participants of the Fifth Workshop of the Global Collaboratory on the History of Labour Relations (Düsseldorf, I 2-I 4 November 2009) for their comments on earlier drafts of this article.

I. Catharina Lis and Josef Ehmer, "Introduction: Historical Studies in Perceptions of Work", in Josef Ehmer and Catharina Lis (eds), The Idea of Work in Europe from Antiquity to Modern Times (Farnham, 2009), pp. I-30, 24.
} 
One such individual thinker was the seventeenth-century Dutch artisan Pieter Plockhoy. His stance on the ethics of work can be reconstructed from one of the three short tracts he published in the late 1650 s and early I660s. Plockhoy did not write about work for the sake of it - in this he seems to have been no different from those artisans studied by James Amelang who left autobiographies. ${ }^{2}$ What mattered to Plockhoy, and why he wrote his tracts, was the question of how a true Christian should live. Nevertheless, as will be seen, work was a central component of Plockhoy's philosophy of true, practical Christianity. It is therefore possible to extract a more or less coherent ethics of work from his tracts.

Plockhoy's work ethic is all the more interesting in that he was an artisan, not one of "the leisured or the recipients of the state's or a patron's largess", able to devote more time and energy to thinking about work and its ethics. His thought therefore can give a small, written voice to "the humble" who, to quote Herbert Applebaum, "speak [only] through their work and the objects they create". ${ }^{3}$

In this article, Plockhoy's personal ethics of work is reconstructed and contextualized by following the seven-layered structure of investigation developed by the Collaboratory. ${ }^{4}$ Given that Plockhoy is hardly a household name even among specialists of seventeenth-century thought, a brief introduction to the life and thought of Pieter Plockhoy is appropriate here.

\section{PIETER PLOCKHOY: AN INTRODUCTION ${ }^{5}$}

Pieter Plockhoy was born in the Dutch town of Zierikzee in the southwestern island province of Zeeland, but as a young man he settled in the Zeeland capital, Middelburg, where he married and started a family, made a living as an artisan - presumably either as a carpenter or tinsmith - and played an active role in the local Mennonite congregation. From i649 until late 1652 he was one of the congregation's unsalaried ministers, but from the start Plockhoy was highly controversial, perhaps because of the heterodox religious opinions he would espouse later in life, but certainly because of his loose sexual morals. His refusal to accept censure led eventually to his expulsion from the congregation in 1654 .

A few years afterwards Plockhoy travelled to London, at the time a hotbed of religious heterodoxy, where he seems to have lived between the

2. Ibid., pp. 7, 26; James S. Amelang, "Lifting the Curse: Or Why Early Modern Worker Autobiographers Did Not Write about Work", in Ehmer and Lis, The Idea of Work, pp. 9I-Io0, 93.

3. Herbert Applebaum, The Concept of Work: Ancient, Medieval and Modern (Albany, NY, I992), p. xii.

4. See for this the Introduction to the present volume.

5. The following section is based on my thesis, "'Born to the Common Welfare': Pieter Plockhoy's Quest for a Christian Life (c.1620-1664)" (unpublished Ph.D., European University Institute, 2009). 
middle of 1657 and late I660. He wished to discuss the vexed issue of church settlement with the English Lord Protector, Oliver Cromwell. England had been without a settled church since the early I640s, a situation deplored by virtually everyone but the dissenters - such as Plockhoy, who advised Cromwell not to set up a new state church but to found meeting places where everyone would be at liberty to discuss Scripture. Cromwell happened to be sympathetic to Plockhoy's ideas, but died shortly after. His son and successor had no interest, and Plockhoy eventually published his correspondence with the Cromwells in an attempt to win over parliament to his views on confessional policy. This tract, The Way to the Peace and Settlement of these Nations, was published in 1658, and went through two editions. In The Way, Plockhoy argued that the government should steer clear of attempts to lord over the conscience of its subjects - which is a sin - and instead set up meeting places all over the country, where everyone should be allowed to speak freely on religious matters. According to Plockhoy, that would be the only way to ensure civil and internal peace.

While trying to influence government policy, Plockhoy also promoted a second project, which he publicized in $A$ Way Propounded to make the Poor in these and other Nations Happy, published in 1659. This tract is the main source for reconstructing Plockhoy's ethics of work. Partly a response to the dire poverty he had seen in England, in $A$ Way he set out a blueprint for a "society or little commonwealth" in which artisans, farmers, mariners, and scholars might combine and pool their, usually limited, resources. Rather than struggle individually on the brink of poverty, Plockhoy envisioned them as working together for the greater good of all, avoiding sin, and living according to Christ's tenets. The little commonwealth would strive for economic autonomy and the community's combination of cost-saving and diligent labour would result in a profitable enterprise, Plockhoy hoped.

Unlike his attempt to influence government policy, $A$ Way became a runaway success of a sort, for it went through at least six different editions between 1659 and the spring of I660. Plockhoy came close to realizing his "little commonwealth", but in the end this project came to nought too, probably because the monarchy was restored in 1660 . Plockhoy returned to the Dutch Republic, to Amsterdam, where he attended the free-speech colleges of heterodox Christians and became notorious for publicly defending polygamy. Taking advantage of Amsterdam's desire to populate its American colony, Plockhoy concluded a contract with the Burgomasters to set up a colonial settlement where he hoped to establish his "little commonwealth". In the summer of 1662 he published his third tract, Kort en Klaer Ontwerp ["Short and Clear Design"], which is based largely on the blueprint he outlined in $A$ Way.

In July 1663 Plockhoy and his fellow colonists finally disembarked near what is now the town of Lewes, Delaware, and founded a settlement there. 
Fourteen months later, however, the Dutch colonies in North America were seized by the English, and Plockhoy's settlement was destroyed in the process. What happened to him is unclear; six years later his widow and children were living in Amsterdam, but where and when exactly Plockhoy died is unknown.

\section{PLOCKHOY'S ETHICS OF WORK: A RECONSTRUCTION}

Plockhoy never formulated a coherent world view in his writings, and his ethics of work must be reconstructed on the basis especially of his second tract, A Way. His third tract, Kort en Klaer Ontwerp, is mainly an abbreviated version of $A$ Way, but differs in some details. Plockhoy's tracts had a specific purpose, namely to promote practical solutions to what he perceived to be society's ills, ${ }^{6}$ and are therefore limited in their scope and coverage of themes. Furthermore, all three of his tracts served to attract the support of the powerful and the wealthy and will have been written in such a way as to minimize the risk of antagonizing prospective sponsors.

There is thus a real danger that any reconstruction of his ethics of work will remain fragmentary. Nonetheless, the attempt will not be without its rewards, since these tracts show how an artisan, engaged with the problems of his day, thought labour should be conducted and rewarded. As his thought was firmly rooted in the Christian thinking that pervaded his age, Plockhoy's solutions were mandatory rather than optional in as much as they conformed to Christ's tenets. His texts are thus prescriptive, reflecting on what could be and should be rather than what actually was. But they are also, in a lesser sense, descriptive in that Plockhoy occasionally refers to how one should do one's work, and what working practices were unacceptable to him.

\section{THE CENTRALITY OF WORK}

To Plockhoy, who like many of his contemporaries aspired to be a "true Christian", work was an integral part of Christianity. His concern with work, however, went further than with most of them: his proposal for a "little commonwealth", or "society" as he called it, was designed in principle for the workers in society, the great part of humanity which had to work to make a living. To Plockhoy, the primary division within society was between those who had to work - either with their hands or with their brains - and those who did not have to, or did not want to. In a truly Christian society everyone should contribute to the common good by spending their time usefully, and Plockhoy clearly disagreed with

6. The particular social ills Plockhoy wanted to redress will be discussed in greater detail later in this article. 
those who believed that the wealthy need not work. Idleness was a sin. In his view,

Princes are not born on purpose to reare up stately Palaces, the Learned are not born for the writing of many unprofitable, and for the most part frivolous Books; the rich are not born to boast of their gold, silver, and christal vessels; the rest of the people are not born for so many various unprofitable Handy-crafts. ${ }^{7}$

Princes, scholars, the rich and the poor alike were to use their stations in life to work for the greater good of society, which was part of the Christian duty of working towards the goal of one's salvation.

Work was essential in a Christian's life, and it could hardly be anything else in an age so steeped in biblical lore. Everyone knew Genesis, 3.19: "In the sweat of thy face shalt thou eat bread, till thou return unto the ground." But sweating was one thing, back breaking quite another. To Plockhoy, work should be in proportion to other things in life, especially the time spent on more elevated activities. Normally, one would labour from dawn to dusk, but working until body and spirit were exhausted was not conducive to attending to one's spiritual obligations. Thus, Plockhoy envisioned a working day of only six hours, three in the morning and three in the afternoon, or divided in whatever way it suited the society's members, so that they could bestow "the rest of their time, for the refreshing of their bodies, and profitable excercises of the mind". ${ }^{8}$ Like adults, children should not work more than six hours a day so that they could spend their time "in other usefull imployments, that they may be fitted for some what ells beside working".

Plockhoy was less generous to the wage workers employed by the society: they should work the normal average of twelve hours a day, from dawn till dusk, "till any of them be fit and willing to come into us", ${ }^{10}$ that is, to become a full member. Plockhoy thus offered an incentive to become a member of the society, but he was also more generous than the average employer by offering the possibility of advancement, and improvement of working conditions. Offering this incentive might have been connected with the opprobrium attached to wage labour in Plockhoy's day. In England at least, artisans and husbandmen greatly disliked being reduced to wage labour and looked down on the landless wage labourer. ${ }^{\text {I }}$

7. Peter Cornelius van Zurik Zee [pseudonym of Pieter Plockhoy], $A$ Way Propounded to make the Poor in these and other Nations Happy (London, 1659), p. 3 I.

8. Ibid., p. 4 .

9. Ibid., p. I2. Though Plockhoy did not elaborate here on what these "other usefull imployments" might be, it is probable that he was referring to a study of the Bible and of the "natural Arts, Sciences and Languages"; ibid., p. is.

Io. Ibid., p. 4.

I I. For many examples of this interesting but understudied phenomenon, see Christopher Hill, "Pottage for Freeborn Englishmen: Attitudes to Wage Labour in the Sixteenth and Seventeenth Centuries", in G.H. Feinstein (ed.), Socialism, Capitalism and Economic Growth: Essays 
Every member of his society should work, preferably, with perhaps the exception of the intellectual workers, with his hands. What was in Plockhoy's eyes perhaps the most sinful occupation - that of merchant - was not to be a separate profession at all: instead, all artisans were to sell their own products, taking turns, the artisans normally residing in the society's rural settlement, with only the temporary "merchants" staying at the urban settlement. What work merchants normally did - the keeping of accounts - Plockhoy hoped to entrust to those young members of the society with a head for figures. They would be instructed in "Ciphering, and keeping Books of accompts", in order to assist the merchant-artisans so "that the merchants also may sometimes work". ${ }^{12}$ Plockhoy applied the same principle to the mariners, who in foreign parts were to act as the society's merchants. ${ }^{{ }^{3}}$ Plockhoy's dislike of merchants stood in a long tradition of Christian thinkers distrustful of merchants, who were regarded as especially prone to succumb to the capital sin of greed. ${ }^{\mathrm{I}}{ }^{4}$

Plockhoy was consistent in his insistence on the centrality of work in the life of actual society members. But just as the society's wage workers were expected to work a normal working day, so Plockhoy also kept open the possibility for wealthy and godly supporters of the society, who shared its concern for practical Christianity, to live there without the obligation to work. ${ }^{\text {Is }}$ Instead they were expected to pay their fare and lodgings from their own capital. But if they did do some work for society, Plockhoy would applaud it and they would "hold forth a good Example to all rich time-loosers in the world". ${ }^{16}$ For the "Children of rich people",

Presented to Maurice Dobb (Cambridge, 1967), pp. 338-350. He even speaks of "the 'ideological' hostility to the status of wage labourer"; ibid., p. 338 . See also Applebaum, The Concept of Work, p. 367. It would be interesting to see how widespread this antipathy to wage labour was, and whether it also existed outside England. There is certainly some evidence that it did: in Renaissance Milan, for poor guild masters and workers to become wage labourers meant the loss of dignity, pride, and control over their means of production. See Luca Mocarelli, "The Attitude of Milanese Society to Work and Commercial Activities: The Case of the Porters and the Case of the Elites", in Ehmer and Lis, The Idea of Work, pp. I0I-I 21 , I०8.

I 2. Plockhoy, $A$ Way Propounded, p. 8.

I3. Ibid., p. 7.

I4. Lis and Ehmer, "Introduction", p. I5. Thomas Aquinas typically rated merchants and shopkeepers lower than farmers and artisans; see Jaume Aurell, "Reading Renaissance Merchants' Handbooks: Confronting Professional Ethics and Social Identity", in Ehmer and Lis, The Idea of Work, pp. 71-90, 86-87. Another example of a critic of merchants and their behaviour is the sixteenth-century Italian monk, Tomaso Garzoni; see Luca Mocarelli's contribution to the present volume.

I 5. I use the term "godly" to refer to all those people who - whatever other differences they might have had - shared a common concern for acting and thinking as a true Christian. What that meant was often debated, as was the question of who exactly was "godly", but that does not detract from the fact that they all shared this concern.

16. Plockhoy, $A$ Way Propounded, p. 5. The idea that time needed to be spent usefully was much older: for example, in the sixteenth century the theme of good and bad use of time was popular as the subject of prints in the southern Netherlands; see Ilja M. Veldman, 
who, Plockhoy hoped, would attend the society's school for instruction in "Arts, Sciences and languages", there was no escape from labour however. They would be expected to work three hours a day at school, "learning some usefull Trade", so that if they or their parents lost their wealth they might still be able to earn their bread "without being necessitated to fall upon such courses [...] as may prove hurtfull to their souls and bodies". ${ }^{17}$ For the members there was no escape from work, but they would enjoy a better balance between work and life. Thus, in Plockhoy's envisioned society the active life and the contemplative life were to be combined, for the greater good of Christian society in general and his little Christian commonwealth in particular.

\section{WORK AND WORKERS IN THE SOCIAL ORDER}

In Plockhoy's view, Christ had done away with hierarchy among Christians, "Abollishing amongst his disciples, all preheminency, or domineering, of one over another", and declaring that his followers should regard themselves as equal brothers. ${ }^{18}$ For a radical Christian such as Plockhoy, this meant that all human hierarchies were pointless. What mattered to one's salvation was not one's status in life, but one's faith, and acts of faith. Plockhoy reflected that "The world hath her delights in different degrees of Dignities, States, Titles, and offices; exalting themselves above another"; Christ, however, had willed "that everyone shall perform his office as a member of one and the same body". No one should therefore exalt himself or account himself worthier than the other. ${ }^{19}$

Consequently, Plockhoy had no interest in defining a particular social order: all Christians should be one under Christ. His tracts are therefore not explicit about the role of the worker in society, in terms of actual status, place in the hierarchy, or economic position, nor did he make a distinction within his own little society. What hierarchy there was in his society was based on proven skill and individual leadership qualities, not on inherited status or monetary wealth. This in itself was a radical departure from practice in seventeenth-century Dutch and English society, in which even guilds could be largely oligarchic in nature, the wealthier guild brethren dominating the guild leadership. In Plockhoy's society the governor of the society would be chosen not "for his riches or wealth [...] but for his wisdom". ${ }^{\circ}$ All positions of leadership, including the governorship, were

\footnotetext{
"Representations of Labour in Late Sixteenth-Century Netherlandish Prints: The Secularization of the Work Ethic", in Ehmer and Lis, The Idea of Work, pp. I49-175, I58-163.

17. Plockhoy, A Way Propounded, p. 4.

I8. Ibid., p. 24.

19. Ibid., p. 25.

20. Ibid., p. 9.
} 
for one year only. ${ }^{21}$ Moreover, the governor's leadership was confined to the executive - collectively, all members of the society formed the legislative. Leadership was also accountable: every six or twelve months "an account shall be given". The treasury of the society would be entrusted to three men: the treasury chest would have three locks, and "three of the uppermost in the Government, shall allwayes have the keyes", so that the chest could be opened only if all three were present. ${ }^{22}$ As the governor was chosen on merit, so were the masters who oversaw their fellow artisans: the best workmen would be appointed to that responsible position. ${ }^{23}$

All status within the society thus depended on merit, election, and accountability, and all members were otherwise equal. Plockhoy's society was both egalitarian and democratic, and espoused a work ethic to which all members were to subscribe. It is likely that Plockhoy believed that these principles of organization applied to all organizations of "true Christians". That life in fact rarely conformed to "true Christianity" was of course the main reason for founding his community.

Though Plockhoy did not set out to write a systematic analysis of the position of the workers in society in his time, what he wrote about life outside his proposed community is enough to get an impression of what he believed to be the common lot of the average worker. A whole section of $A$ Way is devoted to the ills to which an artisan's life was subject outside Plockhoy's community: sickness, lack of trade or work, loss of customers, poverty, and debt, ${ }^{24}$ inability to marry and found a family because limited resources could not provide for one, parents struggling to give their children a sound basis for starting out in life, the young struggling to attract and keep customers, mental depression induced by one's economic distress, the breakdown of marriages when material success remained elusive, early death leaving their wives as widows and their children orphans, and the widows often unattractive on the marriage market precisely because they were hindered by the mouths they had to feed. ${ }^{25}$

In the outside world some artisans with physically demanding occupations, such as smiths and carpenters, had to undergo "allmost intollerable labour" for twenty to thirty years in order to save and invest some money, only to lose the investment or die before reaping the rewards of their hard labour, which then might end up in undeserving hands. Even if they lived long enough to enjoy the results of their hard work, often their bodies were so "spoiled with working" that they "suffer them

2I. Incumbents could stand for re-election though, since, in Plockhoy's opinion, "he that hath a mind to continue in the Government will have an Inducement to rule well”; ibid.

22. Ibid.

23. Ibid., p. I I.

24. Ibid., p. I 2.

25. Ibid., p. Is. 
to take no rest". If they have not been able to save enough money, an old age awaited them in "Hospitalls of old men and women", whose inhabitants "come in out of necessity [...] with their contentions, opposition, and deeply rooted Infirmities, [...] their bodies by hard labour spoiled and made decrepite, and their mindes corrupted by evil manners, being many times, beside a deep stupid ignorance, so ill natured, that no reason can sink into them". ${ }^{26}$ There can be no doubt that in Plockhoy's eyes such an end was hardly conducive to attaining salvation. The place of the average worker in society was thus one of constant anxiety and imminent material and spiritual ruin.

Against this bleak image of the average worker's life in the world outside, Plockhoy projected his community as the solution to all of these ills. A member of the society would never "stand singly by himself alone", and "there will be no need [...] to take any care or to make provision for the aged time, or day of sickness, nor for the children", for whomever became unable to work by sickness or old age, or left widows and orphans behind, would be provided for by the rest who, "being united as members of one body", would work for them. ${ }^{27}$ In Plockhoy's society the solidarity of its members would ward off all the disastrous consequences of personal misfortune and the accompanying propensity to sin, so that the members would not have just to fret about their material and social position, but could also turn their minds to higher things - not the least of which is their salvation. In fact, the society itself would assist its members to work towards salvation, for it was Christ,

[...] who by his Doctrine and example, hath instituted a partnership or Society of mutuall love $[\ldots]$ requiring that the gifts, and meanes of subsistence in the world $[\ldots]$ should be Common [...] so that all Christendome ought to be meerly, a certain great fraternity consisting of such as $[\ldots]$ conspire together in

26. Ibid., p. I3. Though there is no evidence that Plockhoy read Classical writers, the detrimental effects of labour on body and mind was also a topos in ancient Greece; Catharina Lis, "Perceptions of Work in Classical Antiquity: A Polyphonic Heritage", in Ehmer and Lis, The Idea of Work, pp. 33-68, 40-4I, 47. It could also be heard on occasion in, for example, Renaissance Venice; Mocarelli, “The Attitude of Milanese Society to Work”, pp. 107-109.

27. Plockhoy, A Way Propounded, p. I3. Plockhoy might have been inspired by, but goes much further than, the provisions for mutual assistance offered by many early modern Dutch guilds, which might "insure" their members against the consequences of sickness, temporary lack of work, or even the costs of old age and death; see Sandra Bos, "Uyt liefde tot malcander". Onderlinge bulpverlening binnen de Noord-Nederlandse gilden in internationaal perspectief (I570-I820) (Amsterdam, I998) for a general overview, and the autobiography of the Amsterdam furrier, Hermanus Verbeeck, Memoriaal ofte mijn levensraijsinghe, J. Blaak (ed.) (Hilversum, 1999), for one particular example. It should be said, though, that the mutual assistance provided by guilds could be haphazard and dependent on how successful a certain incorporated profession was. In Plockhoy's native Zeeland, for example, this mutual assistance seems to have been meagre; see L.H. Remmerswaal, Een duurzame alliantie. Gilden en regenten in Zeeland, I600-I800 (Utrecht, 2006), pp. II7-I25. 
Christ, the sole head and spring of love; doing well to one another, and for his sake distribute their goodes to those that stand in need. ${ }^{28}$

It is this idea of partnership, or a society of mutual assistance, that is closely intertwined with Plockhoy's ideas on how his society should interact with the world outside. Plockhoy did not believe in a transformation of all human society along the lines of his ideals, but preferred to realize his ideal society as a private enterprise, a community of like-minded people not of the world, but in the world. As we have seen, Plockhoy's society was open to wealthy and godly people and their children, provided they paid for the privilege. Plockhoy also hoped that they would patronize the shops of the society, as the products of the society were to be sold to outside customers. ${ }^{29}$ The key to profitable trade, and thus to making the society a success, was collaboration between its members, which would save costs and manpower normally otherwise engaged, thus enabling, for example, three-quarters of the female labour force to be employed for the common good. ${ }^{30}$ Thus the society would be able to produce more cheaply, the profitability of the enterprise increase, and its participants assured of their material well-being.

The place of Plockhoy's society is thus rooted firmly within the wider structure of society as a whole, but the role of its constituent members is materially and spiritually - radically different from that of their counterparts in the world: instead of being isolated and subject to the whims and wiles of affluent customers who are their social betters, united in their little commonwealth they can become a commercial force to be reckoned with. Within the framework of the Collaboratory's taxonomy of labour relations, Plockhoy's ideal was of a community engaged in reciprocal labour, but producing its surplus for the market in the outside world.

\section{FREE AND UNFREE LABOUR}

This commercial power of unison also brought with it an aspect which brings us to the fourth layer of investigation: the acquisition of freedom to work where, when, and for whom one wanted. To Plockhoy any form of unfree labour was unacceptable, as it would be irreconcilable with the egalitarian structure of his little commonwealth. Plockhoy used the word "slavery" only in a pejorative sense, ${ }^{3 \mathrm{I}}$ as becomes clear from the observation that "evil Governours or Rulers, covetous Merchants and Tradesmen,

28. Plockhoy, A Way Propounded, p. 24.

29. Ibid., p. 7.

30. For this in greater detail see the first paragraph of "Who May Do What Work?" below.

31. Elsewhere he writes how "unprofitable, and hurtfull handy Crafts" were not just the cause of sin, but also of slavery, though he does not elaborate on this; Plockhoy, A Way Propounded, p. 34. He might have believed that those handicrafts which were unprofitable would force people to resort to wage labour, or to be exploited by others. 
lazie, idle and negligent Teachers, and others, have brought all under slaverie and thraldom". ${ }^{32} \mathrm{He}$ used the word also for arrangements in society which were not slavery in a legal sense, but which limited the freedom of employees, such as the system of binding apprentices in England, in which the young could be reduced to unfree labour. ${ }^{33}$

Since the Elizabethan Statute of Artificers and Apprentices was promulgated in is 86 all would-be artisans were forced to undergo an apprenticeship of at least seven years. In practice this meant that employers were offered seven years of cheap labour, and in many cases apprentices were exploited, malnourished, or did not actually learn a trade. $^{34}$ In his proposed community by contrast the children would "always [be] chearfull by not being oppressed with bondage and slavery, as common is seen amongst children of the World, especially in England, who must endure [...] to pass through 7 years, as slave under the Turk". That was a strong condemnation, for slavery in a Muslim country was regarded as particularly dangerous to the soul, as it often entailed forced conversion to Islam. It was therefore greatly feared by Dutch sailors, many of whom came from Plockhoy's native Zeeland.35 Plockhoy was thus highly critical of the English system of apprenticeship.

No wonder then that in Plockhoy's community the apprentice system would not apply, so that the children would always remain with their families. ${ }^{36}$ Plockhoy regarded not just apprenticeship but any form of service as nothing short of slavery, writing for example that "many young men and maides being wearied under the slavery and service" of "hard, strict, severe Masters and Mistrisses" would be willing to join his community. ${ }^{37}$ In this

32. Ibid., p. 3 .

33. Children of the poor could be forcibly apprenticed by judges; see David Eltis, "Labour and Coercion in the English Atlantic World from the Seventeenth to the Early Twentieth Century", in Gad Heuman and James Walvin (eds), The Slavery Reader (London, 2003), pp. 58-73, 59. 34. Applebaum, The Concept of Work, pp. 274-275.

35. For this see in general R.C. Davis, Christian Slaves, Muslim Masters: White Slavery in the Mediterranean, the Barbary Coast, and Italy, I500-I800 (New York, 2003). For the specific Dutch fear of forced conversion see Gerard van Krieken, Kapers en kooplieden. De betrekkingen tussen Algiers en Nederland I604-I830 (Amsterdam, I999), pp. 104-108, and P. Boon, Een Westfriese Zeeman als slaaf in Barbarije, verslag van de belevenissen van Jan Cornelisz Dekker in Marokko, I7I5-I743 (Schoorl, 1987), pp. 44, 67-70.

36. Plockhoy, A Way Propounded, p. I I. Note that Plockhoy saw nothing wrong in child labour. The children and those who were under age would work half a day "so that they, being freed from slavery, may not decline into laziness or carelessness" [op datse van slavernije bevrijd sijnde, tot geen luyigheyd ofte on-achtsaembeyd mochten komen te vervallen]; idem, Kort E Klaer Ontwerp, p. 8. That would have been detrimental to their souls. What Plockhoy objected to was child labour that was not conducive to a Christian way of life.

37. Idem, A Way Propounded, p. I4. Especially because then there would be no restrictions on marriage and pregnancy, as was normally the case; Eltis, "Labour and Coercion", p. 59. The Dutch Republic was an exception to this rule. 
context it is perhaps telling that many early modern Englishmen regarded wage labourers as unfree. ${ }^{38}$ Plockhoy may have shared this idea, even if he never says so explicitly.

Slavery in a legal sense was hardly an issue in England or the Dutch Republic, where it was forbidden, but it was a different matter in their colonies. ${ }^{39}$ Once Plockhoy had embarked on his colonial venture he needed to take a clearer stance on the issue. In the prospectus for his American colony he explicitly stated that "we do not want to burden our Company with domination or subjugating slavery" ${ }^{4}$ This terse statement meant that Plockhoy would not allow chattel slavery in his colony, nor would there be room for indentured labour, another well-known feature of labour in English colonial society. ${ }^{4 \mathrm{I}}$

In Plockhoy's community labour was also free in other ways. The wage labourers serving the society were not destined to remain wage labourers forever, as often happened in practice in the outside world: if they wanted to, they could join the society. Guests staying temporarily were free to pay for the hospitality they enjoyed with money or labour. ${ }^{42}$ The young members of the society would enjoy another labour freedom: they were to be taught two or even three crafts, so that they would always find work even if their main craft were no longer profitable owing to changes in fashion. ${ }^{43}$ Implicitly that also allowed them to change occupations if they wanted to. Furthermore, members of the society were free to leave the little commonwealth, with generous farewell bonuses, such as their share of the surplus accumulated during their membership. ${ }^{44}$ Therefore, opting for the society did not compromise one's liberty.

Such freedom of choice was unheard of - once one had become a member of a certain guild, it was not so easy to make a career shift to another occupation. To be sure, artisan's sons could choose an occupation different from that of their fathers, and this often happened in both England and the

38. As Hill put it: “There is plenty of confirmatory evidence for Professor MacPherson's argument that in the sixteenth and seventeenth centuries those in receipt of wages were regarded as unfree"; Hill, "Pottage for Freeborn Englishmen", p. 342.

39. In fact, labour was normally free in the Dutch Republic, and contract-based; Jan Lucassen, "Labour and Early Modern Economic Development", in Karel Davids and Jan Lucassen (eds), A Miracle Mirrored: The Dutch Republic in European Perspective (Cambridge, 1995), pp. 367-409, 386, 395.

40. "Alsoo wy met geen heerschappije ofte knechtische slavernije onse Compagnie en willen belasten"; Plockhoy, Kort \& Klaer Ontwerp, p. Iо.

4I. On indentured labour see, for example, David Eltis, "Slavery and Freedom in the Early Modern World", in Stanley L. Engerman (ed.), Terms of Labor: Slavery, Serfdom and Free Labor (Stanford, CA, I999), pp. 25-49, 27, 30, 4I.

42. Plockhoy, A Way Propounded, p. 8.

43. Ibid., p. I2. A real danger, as the furrier Hermanus Verbeeck experienced; Verbeeck, Memoriaal, pp. I2, 69.

44. Plockhoy, A Way Propounded, p. 6. 
Dutch Republic, ${ }^{45}$ but once established in a trade it was not easy to change career paths. Plockhoy's plan ensured that the society's children would be more occupationally mobile and thus more employable.

\section{THE RANKING OF OCCUPATIONS}

This brings us to the next layer of investigation. To Plockhoy, all useful trades were equal and perhaps therefore interchangeable, but this did not apply to those occupations deemed useless. The distinction between useful and profitable occupations and those that are not is the only form of ranking Plockhoy makes. For the foundation of his society he needed men from four categories: husbandmen (a generic term for all agricultural labourers), mariners (likewise for all maritime labourers), "Masters of severall Arts and Sciences", and "Usefull Handy Craft-people", ${ }^{6}$

What occupations he considered useful, if not necessary, becomes clear from the lists of necessary occupations, mostly of an artisan nature, he attached to his tracts. ${ }^{47}$ These lists contain such artisan evergreens as smiths, masons, carpenters, cobblers, and weavers, but also more specific occupational niches, such as glovers, bleachers, compass-makers, spectacle-makers, and distillers. The lists were clearly not meant to be exhaustive, and they differed slightly. ${ }^{4}$ With the exception of that of physicians, only artisanal occupations featured in these lists, though perhaps Plockhoy regarded the work of physicians as an artisanal form of work rather than the intellectual occupation its practitioners considered it to be.

Elsewhere in his tracts Plockhoy divided the agricultural labourers into husbandmen proper and gardeners, ${ }^{49}$ and the "Masters of severall Arts and Sciences" into at least four categories: first, "one that can write extraordinary well"; secondly "another that understands arithmetick, Geometry, Astronomy, Navigation, Italian book-keeping or Merchants Accompts"; thirdly "some for Latin, Greek, Hebrew and other Languages"; and, fourthly, as a rest category, also for "Physick, Musick, and other usefull things, referring all to a good and spirituall end".$^{\circ}$ The mariners

45. Paul Seaver, "The Puritan Work Ethic Revisited”, The Journal of British Studies, I9 (1980), pp. $35-53,52$.

46. Plockhoy, A Way Propounded, pp. 3, i8; idem, Kort E Klaer Ontwerp, pp. 6, I I.

47. Plockhoy, $A$ Way Propounded, pp. I8-ig (72 occupations: the number, however, varies between the various editions of this tract); idem, Kort $\&$ Klaer Ontwerp, p. I I (63 occupations). 48. The lists are not wholly compatible with each other: thus the list in $A$ Way contains occupations which are not listed in Kort $E$ Klaer Ontwerp. For example occupations relating to the manufacture of paper and books are mentioned in $A$ Way, but not in Kort $\mathcal{E}$ Klaer Ontwerp, whereas the occupation of bleacher is mentioned only in Kort $\mathcal{E}$ Klaer Ontwerp.

49. Plockhoy, A Way Propounded, p. 7.

50. Ibid., p. 6. 
were apparently expected to work simultaneously as fishermen and transporters of goods for the society. ${ }^{\text {I }}$

The typically female occupation of managing the household was not specifically mentioned, but housekeeping is referred to throughout the text and clearly of importance. Plockhoy probably regarded its importance as self-evident. There was no question of ranking typically male labour above typically female labour, although, as will be seen in the next layer of investigation, Plockhoy clearly believed that many women would prefer to work in other occupations.

Useless were those parasitic occupations which Plockhoy regarded as held by those "that have sought and found out many inventions to live upon the labour of others". ${ }^{2}$ Some of those useless occupations may be identified by the fact Plockhoy is silent about them. Soldiers are never mentioned for example, nor police officers. In the latter case Plockhoy probably hoped that by reserving membership to deserving, truly Christian people there would be much less risk of unsocial behaviour. Otherwise he apparently trusted in military and policing protection by the authorities. ${ }^{53}$

Other "useless" occupations are mentioned explicitly in Plockhoy's tracts. As we have seen, Plockhoy had little time for "evil Governours or Rulers, covetous Merchants and Tradesmen" and "lazie, idle and negligent Teachers" - which is how Plockhoy refers to the clergy. ${ }^{54}$ Rulers could not be dispensed with, hence the comparatively detailed description of how and by whom the society should be governed. This indispensability did not, however, apply to merchants and ministers. The covetous merchants have already been dealt with above. Ministers of any kind were another occupational group for which Plockhoy and his society had no use. In Plockhoy's view, "those that are called spirituall persons or Clergy-men" misled the people into believing that they could take care of the people's spiritual needs, so that the people "may the more willingly drudge for them". 55

Instead, however, the faithful could have direct communion with Christ without any form of intercession or mediation, and did not need to be told how to understand the scriptures. "In spirituall things, we acknowledge none but Christ for head and Master", ${ }^{6}$ Plockhoy wrote, and envisioned how his society would facilitate a meeting place where everyone would be free to discuss the scriptures without censure. Ministers were thus as superfluous as

53. In his American plan he does take account of the need to defend his colony by arms; idem, Kort \& Klaer Ontwerp, p. 9.

54. Idem, A Way Propounded, p. 3.

55. Ibid., p. 4.

56. Ibid., p. I6. 
merchants, and Plockhoy hoped that those ministers who were "convinced of their persevering and erroneous teaching" but were "not strong enough to bear poverty" and thus, to the detriment of their souls, remained in their ministry would join his society and publicly renounce their teaching 57 - yet another reminder of the importance of the society as a means to salvation.

Finally, not all handicrafts were considered useful by Plockhoy. Children were to learn only "necessary and allwayes usefull trades", so that they might always earn their living. ${ }^{58}$ What he then regarded as useless handicrafts he does not state explicitly, but as his society is expected to make all things "without unnecessary trimmings" and that clothes should be made "fitted to the body, and convenient for work, without being tyed to fashion, colour, or stuff", the fact that occupations such as jeweller, goldsmith, and furrier are not listed among the "Usefull Handy Craft-people" implies he had little patience for the more frivolous aspects of the growing consumer market of his day. ${ }^{59}$

Plockhoy thus ranked occupations into only two categories: useful and useless occupations. Given his Christian egalitarianism Plockhoy would have regarded all useful occupations as of equal importance to the society, and made no ranking between them. Nor generally did he distinguish between who could and who could not engage in a particular occupation.

\section{WHO MAY DO WHAT WORK?}

As noted above, one way or another every member of Plockhoy's little commonwealth was expected to work. This applied not just to the men, but also to the women and children. Plockhoy clearly believed that women would applaud being freed from the demands of the traditionally female domain of housekeeping, and that his society would give them this freedom: outside his society every woman was obliged to keep house, but in his little commonwealth the resources of women would be used more efficiently since they could combine their efforts. A quarter of the women would therefore suffice to do the housekeeping, such as cooking the communal meals of the society, "the rest $[\ldots]$ being imployed about some work together with men for the common good, which many women will rather do, than to be a whole day troubled with diversities of cares". Three-quarters of womanpower could thus be employed by the

57. Ibid., p. I4.

58. Ibid., p. I2.

59. Intriguingly, Plockhoy adds to his censure of "fashion" and "unnecessary trimmings" that they be "forborn, that God's creatures, which he hath made, be not misused"; ibid., p. I I. Here he seems to be a proto-conservationist. It is striking that even his American colony did not require the services of a furrier, even though the export of beaver hides and other furs was an important part of Dutch transatlantic trade. See Jaap Jacobs, New Netherland: A Dutch Colony in Seventeenth-Century America (Leiden, 2005); and Janny Venema, Beverwijck: A Dutch Village on the American Frontier, 1652-I664 (Hilversum, 2003). 
society, which would profit greatly from the availability of this extra labour force. ${ }^{6}$ The young women of the society should not only "be fitted to do the housewifery" but also be taught "a good Handy-craft Trade", so that if they were minded to leave the society or marry outside it "they may be able to get a livelihood". ${ }^{61}$

Work was thus not necessarily gendered, though some of the required labour was. Housekeeping clearly remained a female domain also in Plockhoy's society, and it seems that decisions about the course to be followed by the society were a male prerogative, since the governor and the masters were spoken of only in male terms. ${ }^{62}$ There was one explicit exception: oversight of the society's victuals would be "governed by turns" by a committee consisting of both men and women. Ten to twelve men and women would govern for six months, after which half of them would be replaced by new overseers, while, to ensure continuity, the other half would continue for a further six months to instruct the newcomers. ${ }^{63}$ The only domain in which women could attain a position of leadership was thus closely connected with traditional female housekeeping tasks.

Though traditional male labour was thus open to women too, this was not the case with housekeeping tasks. Plockhoy must have regarded housekeeping as essential to the society's well-being, but perhaps not as actively contributing to the society's profitability. It is conceivable that even though he allowed women to work in occupations traditionally reserved for men, he was reluctant to have manpower dissipated in work other than that directly conducive to the productivity of the society.

In giving the women of his community the chance to work in whatever trade they preferred, it is likely that Plockhoy was at least partly influenced by the comparatively strong - and growing - labour participation of

60. Plockhoy's notion that this also encourages growth is supported by recent research into early modern female labour in the Dutch Republic, which connects the higher rates of female labour participation with the economic growth of the Dutch Republic. See Manon van der Heijden et al. "Terugkeer van het patriarchaat? Vrije vrouwen in de Republiek", Tijdschrift voor Sociale en Economische Geschiedenis, 6 (2009), pp. 26-52, 46, 50-51. See also Elise van Nederveen Meerkerk, De draad in eigen handen. Vrowwen en loonarbeid in de Nederlandse textielnijverheid, I58I-I8IO (Amsterdam, 2007); Danielle van den Heuvel, Women and Entrepreneurship: Female Traders in the Northern Netherlands, c.I580-I8Is (Amsterdam, 2007); and Marjolein van Dekken, Brouwen, branden en bedienen. Werkende vrouwen in de Nederlandse dranknijverbeid, I500-I800 (Amsterdam, 2010).

6r. Plockhoy, A Way Propounded, p. I0. Plockhoy does not say explicitly that young women should learn a trade to assist in the society's work, but it would be a logical consequence of freeing the labour of women for them to apply their knowledge also within the society.

62. Unfortunately, Plockhoy is vague in the extreme about whether women had a say in the society's legislative and religious meetings: he does not exclude them explicitly, which might suggest that, like many other dissenters of that period, he was not unfavourably disposed to women speaking in public.

63. Plockhoy, A Way Propounded, pp. 9-10. 
Dutch women in his day. Women were active in almost all sectors of the Dutch labour market, though there was a strong labour division between the sexes, ${ }^{64}$ and there were occupations and guilds in the Republic in which women predominated. ${ }^{65}$ Plockhoy may well have based his observation that many women preferred to work with the men rather than be occupied in housekeeping on the fact that many Dutch women worked with their husbands in their trades and shops. ${ }^{66}$

Women outside the Republic often had fewer prospects than Dutch women, and that also applied to England, where Plockhoy first promoted his society. ${ }^{67}$ Nevertheless, for Dutch women too Plockhoy's proposed community would have offered even greater freedom of choice as to what work they could engage in. Gender was not an impediment to participating in the market-orientated labour of the society. ${ }^{68}$

There was perhaps a stronger labour division between age groups, between those who had attained majority and those who had not. The young men in his American colony attained majority at twenty, ${ }^{69}$ and so apparently did the women. ${ }^{\circ}$ Plockhoy had no qualms in assigning "young people to do the hardest work", while the elder and more experienced workers would supervise them "for it doth suit the aged to give orders, and the young to obey". During the communal meals, the young unmarried people would wait on the table by turns. ${ }^{71}$ Also, the younger children were apparently expected to work, though the distinction between education and labour seems not to have been made. The children, and all under-age persons, would

64. For a general overview of the way women's freedom of action increased in the Dutch Republic see Van der Heijden et al., “Terugkeer van het patriarchaat?”.

65. See, among others, Bibi Panhuysen, Maatwerk. Kleermakers, naaisters, oudkleerkopers en de gilden (I500-I800) (Amsterdam, 2000), for the relationship between men and women in the tailoring business; Van Nederveen Meerkerk, De draad in eigen handen, for women active in the Dutch textile industry; Van den Heuvel, Women and Entrepreneurship, for female merchants; and Van Dekken, Browwen, branden en bedienen, for women active in the production and trade of beverages in the Netherlands.

66. Van der Heijden et al., "Terugkeer van het patriarchaat?", p. 46.

67. See here, for example, the international comparison drawn by Van Dekken, Brouwen, branden en bedienen, pp. 195-248, especially $234^{-2} 37$ and $247^{-248}$. It seems that other urban societies also offered greater opportunities: in Cologne, for example, there were three guilds whose membership was restricted to women; Applebaum, The Concept of Work, p. 276.

68. Or to participating in the society's administrative and religious meetings for that matter. Plockhoy is very vague about this, and does not explicitly - or implicitly - exclude women. That he was so vague might, however, have to do with the fact that even in his circles it was by no means accepted that women should have an independent voice, and that an explicit avowal of female independence of thought might hinder the establishment of his community.

69. Plockhoy, Kort \& Klaer Ontwerp, p. 7.

70. Although he does not say so explicitly, this can be deduced from the fact that every person over the age of twenty was to share in the profit of the society; ibid., p. 8.

7I. At the table the young men and women sat next to their fathers and mothers, an indication that Plockhoy took parental authority over the young for granted; idem, A Way Propounded, p. Io. 
not work more than six hours a day, so they could spend their time "in other usefull imployments, that they may be fitted for some what ells beside working". ${ }^{2}$ It seems that their other time would be occupied with being taught "the writings of the Saints, and natural Arts, Sciences and Languages" ${ }^{73}$ Education seems to have ended only at the age of twenty, after which the young man or woman became a full member of the society.

In general, however, Plockhoy allowed both women and the young greater scope to engage in labouring activities, in which aspect his proposed community would be much more liberal than usual.

\section{INCENTIVES AND REMUNERATION}

Plockhoy would have regarded the comparative freedom of labour within his society as a major incentive to join his community, but perhaps as great an incentive was the resulting independence from wage labour. Whereas the "traders in the world" oppressed their workmen with heavy labour and low wages, within Plockhoy's society "the gain of the tradesmen will redound to the benefit and refreshment of the workmen". ${ }^{74}$ The members of his society were not dependent on wage labour or the ever uncertain income of the self-employed. They laboured not just for themselves and their immediate family, but united "into one Familie or Houshold-government", ${ }^{75}$ for the good of the whole society, "as if they are one family". ${ }^{76}$ Instead of earning wages for their labour, they worked in principle to be at least self-sufficient, but, beyond that, were entitled to an equal share in the eventual surplus generated by the society's economic activities. Thus, in Plockhoy's little commonwealth, labour was largely reciprocal, as if his society was indeed a household, though supplemented if necessary by the wage labour of outsiders, and active within the wider framework of a market economy.

As noted earlier, Plockhoy believed his society would become a commercial force to be reckoned with, and that it would not only ensure its members assistance in times of need but also actually make a profit. $\mathrm{He}$ clearly believed that this prospect would work as an incentive not just to join his community, but also to work diligently. Profit and the accumulation of wealth were not the primary aim however: the surplus arising from the society's economic activities served both to support all members of the community, but also the poor outside it. ${ }^{77}$

72. Ibid., p. I 2; idem, Kort E Klaer Ontwerp, p. 8.

73. Idem, A Way Propounded, p. I5.

74. Ibid., p. I2. Perhaps Plockhoy is referring here to the practice of subcontracting.

75. Ibid., p. 3 .

76. Idem, Kort \& Klaer Ontwerp, p. 6.

77. This attitude can also be found, for example, in an anonymous tract published in Antwerp in I552, Vanden borgheren hoe dat si onder malcanderen leven sullen; Veldman, "Representations of Labour”, p. I 54 . 


\section{PLOCKHOY'S ETHIC OF WORK IN CONTEXT}

To summarize, in his tracts Plockhoy displayed a work ethic in which work was central to the life of a true Christian. Apart from physical work, the Christian should also make time available for other pursuits, not the least of which was salvation. Work was everyone's duty, and despite providing few details in general he expected all Christians - men and women - to work, in whatever occupation they saw fit, provided these occupations were useful and profitable to the commonwealth. Moreover, they were to work in unison, none of them having a position of responsibility without the qualifications required for it, and with the aim of being able to provide each other with the mutual assistance Christians should render one another. The workers could thus evade the many temptations of sin awaiting them outside the society, where they were much more on their own and risked succumbing to salvation-impeding poverty. In that way Plockhoy's little commonwealth served to help in attaining salvation. Plockhoy's ethic of work was thus deeply and primarily Christian, even though it contained elements which could be regarded as premonitory of later seventeenth-century writing on commerce.

In this, Plockhoy was not alone, but part of a greater whole, and a distinct minority. ${ }^{78}$ His ethic of work may not be applicable to the vast majority of workers in his age, for it was rooted in a vocal subculture, that of the godly. The term "godly" refers here to a wide range of thinkers deeply influenced by Christianity but not necessarily in full conformity with another, especially where it concerns religious doctrine. They are difficult to class, but with regard to work ethics there was more that united than divided them. Underlying their opinions was a widely shared concern with the practice of Christianity, irrespective of whether one was a committed predestinarian Calvinist Puritan or a spiritualist Collegiant espousing freedom of conscience. Despite the theological hostility, all members of the godly minority believed that it was not enough to be Christian in name only: one should also be Christian in practice. Around 1650 they enjoyed a high public profile on both sides of the North Sea, playing a major role in the debates of their time. Their concern was not the ethic of work in itself, but the ethics of Christianity as a whole.

There is certainly much more to be said with regard to the ethics of work if one also takes their writings into account. Space limitations prohibit mentioning more than one case from the other religious extreme, as represented by the committed predestinarian Calvinist Puritan, Nehemiah Wallington (I598-1658), a London turner who was also a punctilious elder of his Presbyterian congregation. ${ }^{79}$ Though Plockhoy

78. Unless stated otherwise, the following paragraph is based on Looijesteijn, "Born to the Common Welfare", ch. 7: "Plockhoy and Practical Christianity in Context".

79. On Wallington, see Seaver, "The Puritan Work Ethic Revisited", and idem, Wallington's World: A Puritan Artisan in Seventeenth-Century London (Stanford, CA, 1985). 
had little patience for the Calvinist church order Wallington espoused, much of Wallington's ethics would have been approved by him. For Wallington, and the Puritan divines whose books he read and sermons he heard, work was a divine blessing, a way to glorify God, and an antidote against sin especially the sin of idleness. ${ }^{8 \circ}$ Its primary purpose was not the acquisition of wealth - which was the sin of covetousness - but to be useful and profitable for oneself, one's family, church, and commonwealth.

This concept of the commonwealth in which God was glorified by diligent labour was a popular one among Puritan divines, and was largely shared by Plockhoy. And like Plockhoy, the Puritan divines too condemned a parasitic existence in the strongest terms. Sobriety and honesty in dealing with one's customers was constantly on the minds of men such as Wallington. In all this, Plockhoy and Wallington did not differ, although Wallington would have recoiled in horror from Plockhoy's religious opinions and hotly disputed Plockhoy's claim that the office of minister was parasitic.

Many other examples could be given here, such as Dutch Mennonites and Collegiants, and English Quakers - often, like Plockhoy, of modest social status - who all wrote tracts on the fragile balance between wealth and soul. ${ }^{8 \mathrm{I}}$ They shared their concerns with Plockhoy, which is not surprising given that Plockhoy was in turn Mennonite, a sympathizer of the Quakers, and eventually active as a Collegiant.

The writings of this godly minority form a fertile source for the study, not just of the concept of practical Christianity as a whole, but also for their accompanying ethics of work. There are clues that much of their ethics was shared by others who did not necessarily share their religious enthusiasm, such as the Levellers and Diggers. The distaste for wage labour among early modern Englishmen is one example, ${ }^{82}$ but perhaps there were other similarities. An artisan such as Wallington greedily imbibed the writings and sermons of Puritan ministers, many of whom were actually from quite humble backgrounds, and tried to live his life to their ethical standards. It is probable that the same applied to the artisan Plockhoy. A closer study of the writings of the godly minority, and an attempt to link those up with a study of their readership, might therefore shed more light on the general development of the ethics of work in Europe.

80. Lis and Ehmer, "Introduction", p. I6.

$8 \mathrm{I}$. Idleness and covetousness were in fact already "unforgivable sins" in the thought of such religious thinkers as Luther, Calvin, and Richard Baxter; see Applebaum, The Concept of Work, pp. 324-325, 330-33I.

82. Gerrard Winstanley, for example, regarded wage labour as slavery; Hill, "Pottage for Freeborn Englishmen", pp. 345-347. 